JOGED: Jurnal Seni Tari

\title{
KESENIAN BANGILUN SAMIGALUH : KAJIAN KEHADIRAN DAN PERUBAHAN BENTUK PENYAJIANNYA
}

\author{
Y. Surojo, Bayu Puji Santosa; Winarsi Lies Apriani
}

Jurusan Tari, Fakultas Seni Pertunjukan Institut Seni Indonesia Yogyakarta

Email: surojo29066@gmail.com; bayupujisantoso1405@gmail.com; winarsilies@gmail.com

\section{RINGKASAN}

Penelitian dengan judul "Kesenian Bangilun Samigaluh Kajian Perubahan Bentuk Penyajiannya" ini menganalisis bentuk perubahan seni pertunjukan khususnya kesenian Bangilun. Mengapa "perubahan bentuk" perlu diteliti, sebab kesenian tari ini unik sekali koreografinya berbeda dengan tarian lainnya. Keunikan tarian ini terletak pada konsep dasar gerak tari yang didasarkan syairnya. Gerakan tari muncul setelah ada apa syair lagunya. Sesuai dengan fungsinya dahulu syair lagu yang disusun untuk kepentingan dakwah dan isinya ajaran hidup manusia telah lebih dulu ada dari pada gerak tarinya. Dalam penelitian ini ditemukan perubahan sistim dan bentuk sajian yang dijiwai dengan jiwa zaman sekarang di mana durasi waktu garapan antara 1 sampai 2 jam, sudah jarang ditampilkan 7-8 jam (semalam suntuk) seperti pada masa kehadiran di masa lalunya. Perbedaan zaman masyarakat pendukungnya yaitu masyarakat Samigaluh sekarang ini sudah berada di kategori masyarakat maju namun tetap menjunjung tinggi budaya gotong royong di pedesaan. Hal ini menjadi kekuatan budaya yang menempatkan kesenian Bangilun tetap pada seni tontonan dan seni tuntunan di tengah masyarakatnya. Di samping itu perubahan bentuk penyajiannya yang tetap unik adalah koreografi gerak tidak bisa lepas dari bentuk syair lagunya. Berubahnya koreografi geraknya sebatas panjang pendeknya lagu dan cara menyambungkannya, sehingga sampai saat ini belum pernah terjadi antara gerak dan musik berjalan sendiri, mereka masih saling ketergantungan.

Kata Kunci: Bangilun, Bentuk Penyajian, Samigaluh 
ABSTRACT

The research with the title: "The Art of Bangilun Samigaluh, a Study of Changes in the Form of Presentation" is a study that analyzes the changing forms of performing arts, especially Bangilun art. Why "changes in form" need to be investigated, because this dance art is unique, the choreography is different from other dances. The uniqueness of this dance lies in on the basic concept of dance movements based on their poetry. Dance movements appear first because of what the lyrics of the song look like. In accordance with their function, the song lyrics that were composed for the benefit of da'wah and the contents of the teachings of human life have existed before the dance movements. In this study, it was found that the changes in the system and form of the dish were imbued with the spirit of today where the duration of cultivation was between 1 and 2 hours, it was rarely shown 7-8 hours (all night) as in the past. The difference in the times of the supporting community is that the Samigaluh community is now in the category of advanced society but still upholds the culture of gotong royong in rural areas. This has become a strong cultural force that places Bangilin art in the art of spectacle and art of guidance among its people. Besides that, the change in the form of presentation that remains unique is that the motion choreography cannot be separated from the form of the song's lyrics. The changes in the choreography of the movement are limited to the length of the song and the way to connect it, so that until now it has never happened between motion and music that runs alone, they are still interdependent

Key Words: Bangilun, Form of Presentation, Samigaluh

\section{PENDAHULUAN}

Mungkin tidak banyak orang luar Yogyakarta atau Jawa Tengah yang mengenal kesenian yang satu ini. Bangilun tumbuh dan berkembang di Kabupaten Kulonprogo, DI Yogyakarta. Kesenian ini berbentuk nyanyian dengan syair Islami, yang diiringi dengan tarian. Konon, kesenian Bangilun berasal dari daerah Magelang, Jawa Tengah. Kesenian ini masuk ke Kulonprogo sekitar 1950. Di daerah itu, dengan kreativitas warga, mereka menambahkan gerak tari ketika syair dikumandangkan. Syair yang dilagukan dengan gerakan tari biasa disebut rodat. Awalnya kesenian Bangilun dipentaskan sebagai bentuk doa kepada Tuhan Yang Maha Esa, kata Subardi, pelaku kesenian 
Bangilun di Dusun Samigaluh, Kulonprogo. (Subardi, 2018).

Tulisan ini akan memaparkan tentang kesenian Bangilun di Samigaluh, yaitu kesenian tradisional yang ditarikan remaja putri membawa properti kipas. Gerak tarinya lincah dengan liyukan badan dan tangan, sekali-sekali dengan posisi berjajar seperti prajurit sedang baris berbaris. Konon tarian ini awalnya bernuansa Islami dengan syairsyair yang berisi keagungan Allah, Tuhan sang pencipta. Iringan terdiri dari jedor atau bedhug, serta bunyi genjring dan kendhang. Pertunjukan Bangilun ada kalanya diselenggarakan pada siang hari maupun malam hari. Tidak jarang dilakukan semalam suntuk. Masyarakat Samigaluh, khususnya desa Pagerharjo sampai saat ini masih memelihara kesenian Bangilun, tetap merasa bangga bahwa kesenian Bangilun sebagai miliknya.

Dua desa di Samigaluh seperti Pagerharjo yang sudah mejadi desa budaya dan Gerbosari sebagai rintisan desa budaya di mana kesenian Bangilun berada, Gerbosari juga terus menjalani proses kemajuan budaya. Seiring dengan perkembangan sosial politik, ekonomi desa dan sosial budaya, di mana potensi masyarakatnya yang agraris itu, kesenian Bangilun mendapat tempat yang baik, sehingga kelahiran dan pertumbuhan nampak subur. Hal ini diiringi pula rintisan desa budaya Gerbosari dan sekitarnya memiliki sebutan desa wisata. Di Kecamatan Samigaluh ini terdapat beberapa potensi wisata alam seperti Sendang Kadewatan, Sendang Kawidodaren, dan Sendang Simbarjojo. Di samping itu masih banyak tempat-tempat yang dikeramatkan bagian dari obyek wisata Suralaya, misal Alang-alang Kemitir di Nglambur, Jonggring Saloka di Klito, Gunung Suralaya di Keceme, Gunung Kendhil di Nglambur, Tegal Kepanasan di Keceme dan Pasetran Gondomani di wilayah desa tetangga Ngargosari (Puji Lestari, 2019).

Permasalahan pengembangan kebudayaan di wilayah kecamatan Samigaluh antara lain adalah generasi muda belum optimal dalam pemahaman tentang kebudayaan. Mereka masih rancu dalam memilah antara kebudayaan, kesenian, dan agama. Di Gerbosari karena masih menjadi desa rintisan desa budaya, maka kesempatan mendapatkan event dan dana belumlah semeriah desa budaya lainnya, berbeda dengan desa Pagerharjo tidak terjadi pergesekan antara agama dan budaya, maka mengakibatkan jarangnya mengetahui dan mengalami peristiwa misalnya Kirab Budaya, Gelar Budaya, dan Gelar Upacara Adat, Kuliner, warisan tradisi (arsitek bangunan lama rumah limas dan joglo) dan lainnya, sehingga apresiasi warga terhadap budaya masyarakat masih rendah. 
Dulu, kesenian ini dipentaskan saat masyarakat melihat ada lintang kemukus yang dipercaya sebagai pertanda akan terjadi bencana. Mereka pun mementaskan Tari Bangilun untuk memohon keselamatan. Namun, seiring perjalanan waktu, kesenian ini dipentaskan pada saat yang dikehendaki. Kesenian ini berisi tiga kelompok pemain penting, yaitu penyanyi, pemusik, dan penari. "Para penyanyi melantunkan syair-syair yang bernafaskan dakwah agama Islam," ujar Widiharsini, pelatih kesenian Bangilun Sedyo Rukun, di dusun Plono Barat desa Pagerhajo Samigaluh, Kabupaten Kulonprogo. (Widhiharsini, 2018).

Nyanyian tersebut diiringi dengan alunan 6 terbang (rebana), 1 bedhuk, dan 1 kempyang. Alat musik ini dimainkan untuk mengiringi 12 penari. Total ada 50 pemain yang terdiri dari 12 penari laki-laki dan 12 penari perempuan, sisanya pemain musik dan vokal. Kelompok Sedyo Rukun telah berdiri sejak 1954, dan sempat berhenti selama 25 tahun. Pada 2007, para seniman bergerak lagi. Seperti kesenian tradisional lain, para tokoh kelompok seni mengakui bahwa regenerasi sangat sulit dilakukan demi melestarikan Kesenian Bangilun. Pasalnya, banyak anak muda sekarang yang belum tertarik dengan kesenian ini, apalagi sebagai penabuh alat musik. Di Kulonprogo, saat ini hanya ada dua kelompok kesenian Bangilun. Pemerintah kabupaten sudah menjadikan Bangilun sebagai kesenian unggulan, sehingga keberadaannya mulai mendapat tempat di hati masyarakat. (Budi Karman, 2019)

Bangilun merupakan seni tari tradisional yang berasal dari Kabupaten Temanggung. Kata "bangilun" merupakan akronim dari B (budaya), A (aliran), N (nenek moyang), G (gerak), I (Indah), L (lestari), U (untuk), N (nasional). Kesenian Bangilun merupakan seni tradisional religius Islami yang berfungsi untuk syiar agama lewat budaya. Bentuk kesenian Bangilun menyerupai kesenian Dolalak dari Purworejo maupun Angguk dari Kulon Progo. Namun demikian bila diamati cukup banyak berbeda. Bangilun didominasi gerak tari berdasarkan syair yang disebut rodatan. Rodatan ini masih berbentuk pakem, artinya setiap syair sudah memiliki gerak baku sendiri-sendiri. Yang dapat berubah adalah penataan koreografinya saja berdasarkan kebutuhan waktunya (Sri Lestari, 2019).

Bangilun terbentuk kira - kira tahun 1900 pada waktu Indonesia masih dijajah Belanda. Penari Bangilun terdiri dari laki laki dan perempuan. Tata busana yang dipakai dalam pertunjukan Bangilun seperti celana panji, baju rompi, topi pet, sabuk yang digunakan sebagai properti juga untuk pengaman, sampur dan slempang. Namun juga terdapat kelompok yang sudah modern 
kostumnya ditambah kain warna - warni juga kaos kaki. Celana panji dan rompi yang digunakan berbahan dasar bludru. Alat musik yang digunakan dalam pertunjukan Bangilun yaitu bedhug/jidhor, terbang, saron, gong dan dalam perkembangannya ditambah musik keybord. Bangilun biasanya dipentaskan sebagai pertunjukan juga hiburan namun pada jaman dahulu digunakan dalam upacara adat saat panen padi.

\section{PEMBAHASAN}

\section{A. Garap Gerak dan Syair}

Kesenian Bangilun lebih merupakan nyanyian yang ditarikan atau menari berdasarkan nyanyian syair yang sudah ada. Koreografi Bangilun memiliki keunikan tersendiri dibanding dengan tarian lain yang masih merepresentasikan gagasan dan ide. Bangilun memiliki cara dan metode garap yaitu nyanyian yang ditarikan tersebut di atas, sehingga cara pandang dan cara analisisnya juga seturut dengan metode koreografinya. Bentuk koreografi Bangilun akan dianalisis sebagai kesatuan proses yang dilewati penata tari dan penari. Perubahan bentuk yang terus terjadi dipandang sebagai cara untuk menanggapi publik/permintaan pasar dengan tetap berdasar koreografi bakunya yaitu konsep "nyanyian yang ditarikan", tidak lebih dari itu. Perubahan struktur sosial masyarakat mempengaruhi panjang pendek koreografi
Bangilun dengan cara mengurangi jumlah nyanyian syair yang disajikan.

Yang menarik dari kesenian Bangilun ini, terutama dalam ditinjau dari sisi garap tarinya adalah ketika melakukan dan menyusun gerak berdasarkan lagu dalam syairnya Bangilun tersebut. Dengan kata lain setiap akan menari, kemunculan gerak wajib berdasar syair yang harus ditentukan terlebih dahulu oleh penatanya. Setiap pola syair telah ditentukan juga pola gerak tarinya. Misalnya syair "ono putri" pola geraknya juga "ono putri”, tidak lazim menggerakkan pola gerak pada syair lainnya. Untuk menentukan banyaknya motif yang dilakukan juga tergantung kebutuhan panjang lagu yang dilantunkan dengan aba-aba pembeduk. Penari tidak bisa berhenti menari di tengah perjalanan lagu. Semua telah diserahkan oleh pembeduk/pengendang yang mengatur laku gerak tarinya. Pembeduk di sini berfungsi seperti pengeprak dalam pertunjukan Wayang Wong, di mana perpindahan gerak, perpindahan gending, memulai dan berhenti, mempercepat dan memperlambat ditentukan oleh pengeprak.

Demikian juga pertunjukan Bangilun, pembeduk menjadi pengatur utama yang harus di "nut" oleh semua komponen pertunjukan. Sebagai garap gerak agar tarian berjalan dengan baik, maka kualitas teknik setiap penari terus dijaga, agar gerak tari 
JOGED: Jurnal Seni Tari

menjadi kompak dan serempak di dalam sajiannya. Bagi penari yang masih lemah dan belum bisa mengikuti penari lainnya, tentu menjadi pertimbangan penata tarinya apakah diganti atau diberikan gerakan lain yang tidak menghambat sajian gerak tari lainnya.

Bila dibandingkan dengan kesenian lain, kesenian Bangilun sangat berbeda. Pada tari sebagaimana lazimnya, gerak diciptakan terlebih dahulu baru iringannya menyusul. Hal ini tidak berlaku bagi Kesenian Bangilun. Kesenian Bangilun awalnya merupakan sajian membaca syair-syair dalam lagu sholawat. Sholawat merupakan syair dan susunan kata yang dirangkai menjadi lagu, untuk mewujudkan makna dan arti wajib dilantunkan senjadi seni suara yang indah dan enak didengar. Maka dari itu diharapkan siapa saja yang mendengar suara keindahan dari pada lantunan sholawat akan merasa damai dan teduh, sehingga lama-lama orang yang mendengar tertarik dan hanyut dalam suasana ritual Islami, sehingga sangat mungkin orang tersebut menjadi ingin ikut di dalam persekutuan umat muslim. Apalagi di sela-sela lantunan lagu diberikan ceramah tentang kebenaran-kebenaran Illahi. Mendengarkan sholawat menjadi jatuh cinta dengan suasana itu,

Semakin penyampaian oral ceramahnya semakin menarik perhatian, maka secara cepat orang di sekitar yang akhirnya banyak yang tertarik dan kemudian menganut agama Islam. Dengan demikian berhasillah dahwah melalui lantunan sholawat itu. Dalam perkembangannya sholawat dinyanyikan sambil berdiri agar lebih bervariatif. Keunikan dari pada garap kesenian Bangilun Samigaluh kelompok "Sedya Rukun" menempatkan gerak tari berdasarkan syair lagu. Dengan kata lain motif gerak mengikuti lagunya. Sebelum gerak tari dimulai terlebih dahulu tampilan syair seperti contoh di bawah ini: 
KESENIAN BANGILUN SAMIGALUH :

JOGED: Jurnal Seni Tari KAJIAN KEHADIRAN DAN PERUBAHAN BENTUK PENYAJIANNYA p-ISSN 1858-3989 | e-ISSN 2655-3171

\begin{tabular}{|c|c|c|c|}
\hline No. & $\begin{array}{l}\text { Uraian Gerak } \\
\text { Tari }\end{array}$ & Hit & Syair Lagu \\
\hline 1. & $\begin{array}{l}\text { Sikap siap } \\
\text { menari } \\
\text { berjajar } \\
\text { sikap berdiri } \\
\text { tegak - sikap } \\
\text { ini sebagai } \\
\text { tanda tarian } \\
\text { akan dimulai } \\
\text { - penari } \\
\text { dengan sikap } \\
\text { penuh } \\
\text { konsentrasi - } \\
\text { menunggu } \\
\text { lagu dam } \\
\text { syair selesai. }\end{array}$ & & $\begin{array}{l}\text { Abe bakare alla } \\
\text { mabe tirja } \\
\text { Abe bakare alla } \\
\text { mabe tirja } \\
\text { Gendere kino } \\
\text { jorali lila la } \\
\text { anguk } \\
\text { Atur priksa } \\
\text { priyantun kang } \\
\text { lenggah ngriki } \\
\text { Atur priksa } \\
\text { priyantun kang } \\
\text { lenggah ngriki } \\
\text { Sepuh anem } \\
\text { miwah para } \\
\text { kakung putri } \\
\text { Sarehne kulo } \\
\text { badhe maulud } \\
\text { Sarehne kulo } \\
\text { badhe maulud } \\
\text { Para mrikso } \\
\text { maulud badhe } \\
\text { mulai } \\
\text { Datan kantun } \\
\text { kang kagungan } \\
\text { dalem ngriki } \\
\text { Datan kantun } \\
\text { kang kagungan } \\
\text { dalem ngriki } \\
\text { Menawi lepat } \\
\text { nyuwun } \\
\text { gunging } \\
\text { pangaksami }\end{array}$ \\
\hline
\end{tabular}

Selanjutnya tarian Bangilun dimulai dengan lantunan syair nomor 10 (Ono Putri) yang syairnya sebagai berikut :

\begin{tabular}{|c|c|c|c|}
\hline No. & $\begin{array}{l}\text { Uraian Gerak } \\
\text { Tari }\end{array}$ & Hit & Syair Lagu 10 \\
\hline 2. & $\begin{array}{l}\text { Badan } \\
\text { mendhak - } \\
\text { kaki kanan } \\
\text { depan } \\
\text { menyilang - } \\
\text { tangan kiri } \\
\text { malang kerik } \\
\text {-tangan } \\
\text { kanan di } \\
\text { depan pusar } \\
\text { ukel - pacak } \\
\text { gulu } \\
\text { berirama } \\
\text { sesuai } \\
\text { langkah kaki } \\
\text { dan } \\
\text { goyangan } \\
\text { badan. } \\
\text { (dilakukan } \\
\text { sesuai } \\
\text { kebutuhan } \\
\text { ruang dan } \\
\text { waktu) }\end{array}$ & $\begin{array}{ll}1 & - \\
2 & \\
3 & - \\
4 & \\
\text { dst.. }\end{array}$ & 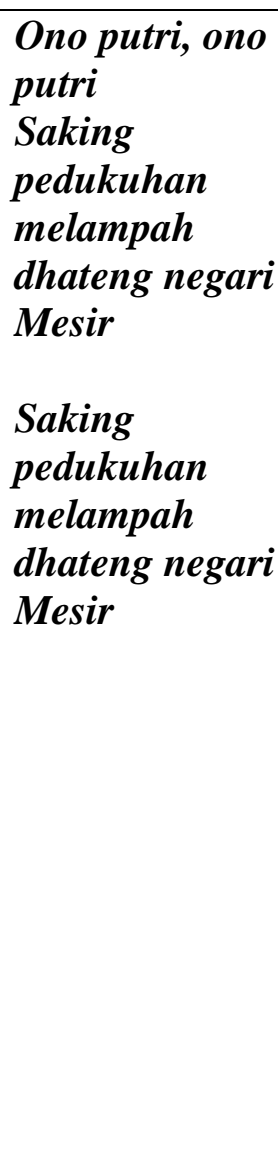 \\
\hline
\end{tabular}

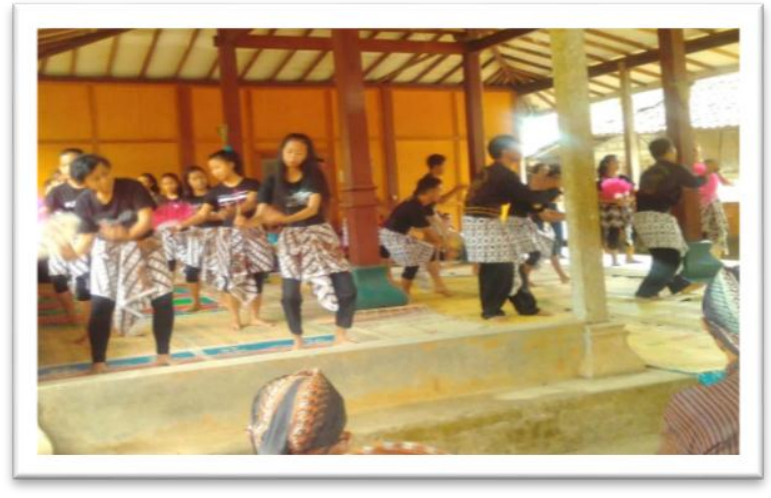

Gb. 01 : Proses perubahan koreografi baru tetapi tetap berpola sebelumnya, gerak tari berdasarkan syair lagu. (foto : Surojo). 
A. Perubahan Bentuk Sajian dan

\section{Pengaruhnya}

\section{Pengaruh Sosial dan Lingkungan}

Kesenian Bangilun hingga saat ini mengalami perubahan bentuk, di antaranya pengaruh sosial masyarakat, terutama masyarakat pemangkunya itu sendiri. Ketika Bangilun mengalami pasang surut perkembangannya, dan karena daerah Pagerharjo merupakan daerah 3 perbatasan, maka kesenian itu menjadi efek positif berhenti di suatu tempat ini. Plono Barat adalah salah satu dusun pemberhentian Bangilun yang kemudian berkembang hingga saat ini. Bangilun sesungguhnya awalnya adalah kesenian tidak asli Pagerharjo, yaitu perkembangan dari daerah Magelang dan Temanggung Jawa Tengah, namun sekarang sudah menetap di daerah Samigaluh dan mendapat tempat yang nyaman sebagai kesenian kebanggaan masyarakat Pagerharjo Samigaluh dan wilayah Kulonprogo pada umumnya.

Ketika masyarakat Pagerharjo selangkah lebih maju dengan predikat Desa Budaya, maka kesenian Bangilun menjadi sangat diperhatikan. Bentuk sajian yang semula masih monoton sekarang sudah dikemas dengan tata koreografi yang menarik, singkat, dan lebih bervariatif. Predikat Desa Budaya membawa wawasan apresiasi masyarakat terhadap seni budaya menjadi lebih kritis.
Bila terdapat sajian yang kurang menarik untuk ukuran dan cara pandang masyarakat sekarang, tidak segan-segan mendapat kritik dan kemudian ada kaji tindak para pengurus Desa Budaya.

Paling tidak berawal dari evaluasi di saat sarasehan, seminar desa, rembug desa, dan rapat-rapat desa menjadikan seluruh kesenian di wilayah Pagerharjo mendapat perhatian dan akhirnya sedikit banyak mengalami perubahan. Cara pandang masyarakat yang kritis itu sebagai kontrol budaya dan dengan kesigapan dan tanggap situasi pengurus, kemudian berupaya bagaimana keseniankesenian itu direvitalisasi kembali. Pengertian revitalisasi adalah menggunakan kembali sesuai dengan fungsinya serta tidak meninggalkan esensi pokoknya. Namun demikian di sisi lain tuntutan zaman sekarang di mana sajian kesenian itu harus padat, singkat, menarik dan tidak menjemukan namun tetap tidak meninggalkan esensi utamanya. Misalnya kesenian sebagai kesenian berawal seni dakwah berbentuk sholawat, namun tetap menggunakan syairsyair yang aslinya.

Sedang bentuk gerak telah menggunakan idiom dan penerapan ilmu menata tari yang ada yang sudah biasa disebut ilmu koreografi. Perpaduan keilmuan menata tari dan esensi pokok seni tradisi ini terjalin dengan baik sehingga untuk menjawab tantangan 
masyarakat di zaman now terwujud. Kesenian

Bangilun sekarang sudah menjadi kesenian dengan garapan baru dengan mengetengahkan elemen durasi pendek, penuh variasi, dinamis/tidak monoton, dan jumlah penari menyesuaikan kebutuhan.

\section{Pengaruh Teknologi Modern}

Semenjak beberapa kali pentas di luar daerahnya sendiri semakin terbuka pula cara pandang seniman Bangilun. Dengan keterbukaan itu menjadi nafas penting bagi kreasinya. Sri Lestari sebagai guru tari dan Budi Karman sebagai pengendali iringan telah menemukan format-format seni menata tari sesuai dengan kebutuhan penanggap/ steak holder. Ketika suatu saat diminta oleh stasiun televisi dengan durasi sangat pendek, maka Budi Karman dan Sri Lestari cepat tanggap untuk mengantisipasinya. Mereka berdua segera menyusun koregrafi pendek yang tetap memiliki esensi Bangilun.

Pada suatu waktu tertentu dihadapkan dengan situasi pementasan yang hanya penari saja, dengan iringan rekaman, maka hal ini pula dikerjakan dengan pertimbangan yang matang. Dengan segala pengertian para pengiring rela untuk mengadakan rekaman suara. Di bawah ini materi sajian motif gerak yang sering dipakai sebagai bahan tataan tari dan sangat luwes dikoreografikan sesuai dengan kebutuhan waktu, antara lain : Abe
Kabare, Anak Kaji, Ing Wajibe, Kembang Cepoko, Salatun Minal Fitri, Кири-kupu, Marikan Cucut, Bangilun E Asalam, Sun Miwiti, Sang Putri Pejajaran, Nogo Rojo, Kyai Sengkelat, Ngelingono, Klapa Muda, kita berduduk-duduk, Raden Supa, Kyai Agung, Jalan-jalan, Encik Amad, dan Allohuma dst...

Dari materi di atas kadang tidak ditarikan semua, namun cukup 7 syair atau 12 syair saja, bahkan pernah hanya 5 lagu/motif saja. Untuk menyesuaikan waktu maka yang digarap lagi adalah pengulangan dan seni perpindahannya yang diolah, sambil membuat pola lantai yang dikehendaki sesuai dengan bentuk arena panggungnya. Ragam sendi merupakan sambungan syair satu ke syair berikutnya dan biasanya untuk membuat pola lantai sekaligus.

Di bawah ini contoh hasil sajian karya Bangilun dengan koreografi menurut kebutuhan, antara lain :

a. Tari Bangilun 5 syair ( $\mathrm{a}, \mathrm{b}, \mathrm{e}, \mathrm{h}, \mathrm{dan} \mathrm{s}$ )

b. Tari Bangilun 7 syair (a, b, p, o, 1, q, dan t )

c. Tari Bangilun 12 syair ( a, b, d, q, l, n, k, $\mathrm{j}, \mathrm{r}, \mathrm{h}, \mathrm{i}$, dan $\mathrm{t}$ ).

3. Perubahan Fungsi

a. Sebagai Sarana Upacara Adat

Pada bagian penting pertunjukan Bangilun yang berkaitan dengan fungsi lansung upacara adat daur kehidupan di 
masyarakat Samigaluh adalah bagian srokal.

Bagian srokal ini berada di bagian tengah di antara susunan syair-syair yang dilantunkan dari seluruh tarian Bangilun. Ketika tepat pada saat ujub adat dilakukan misalnya kithanan atau nadzar lainnya, syair musik srokal dibunyikan dengan cara para pendukung tari berdiri dan justru berhenti menari. Saat inilah pemuka adat/pawang atau orang yang berkompeten mengambil bagian waktu untuk acara ritual dilakukan untuk beberapa menit. Setelah selesai upacara ritual kemudian dilanjutkan lagi pertunjukan Bangilun.

Soedarsono mengatakan dalam perjalanan sejarahnya, kesenian tradisional pada hakikatnya memiliki perubahan fungsi yaitu untuk ritual, untuk sosial, dan untuk tontonan. Kesenian Bangilun yang dahulu kehadirannya dikaitkan dengan peristiwa penyebaran agama/dakwah. Perkembangan selanjutnya sebagai sarana kepentingan adat dan kepercayaan masyarakat yang masih berhubungan dengan peristiwa alam seperti upacara habis panen, orang punya hajad nadzar, adat daur kehidupan manusia peristiwa lahir, hidup, dan mati seseorang dan lain-lain. Namun kini pada prinsipnya fungsi kesenian Bangilun lebih pada seni tontonan saja.

Sebagai seni tontonan yang sesuai dengan jiwa zaman, maka kemudian bentuk tarinya disesuaikan dengan situasi dan kondisi yang diinginkan. Keragaman dan keluwesan fungsi ini membuat kesenian Bangilun bentuknya juga luwes menyesuaikan kebutuhan, sehingga sampai penelitian ini dilakukan tidak terdapat kebakuan bentuk koreografi yang pasti. Setiap akan menyajikan Bangilun sebelumnya dilakukan latihan terlebih dahulu berdasarkan pilihan syair yang dikehendaki penanggap dan peristiwanya. Hal dilakukan sebab setiap syair memiliki makna dan isi dan setiap syair gerak tarinya saling berbeda. Bila ditarikan semua syair lebih dari 60 lagu, namun bila akan menyajikan lagi biasa hanya menggunakan 10 sampai 15 syair. Maka tidak mustahil susunan koreografi dapat berubahrubah tergantung syair mana yang dipilihnya.

b. Sebagai Penguat Sosial dan Identitas Budaya

Sebagai masyarakat yang tinggal di pedesaan, yang lebih mengutamakan kebersamaan dalam kehidupan sehari-hari, kesenian Bangilun telah menjadi obyek penguat sosial. Yang dimaksud dengan penguat sosial di sini adalah Bangilun sebagai kesenian yang dihasilkan karena kerja kolektif serta bermakna sebagai hasil kerja bersama, maka secara tidak langsung memiliki dampak positif memperkuat sistem sosial mereka para pelakuknya. Tidak hanya ini saja, dampak dari kebersamaan kolektif 
tersebut membawa kesenian Bangilun menjadi wahana kegiatan yang bersifat sosial, misalnya ketika berbagai program masyarakat terjadi. Kebiasaan masyarakat di desa yang menekankan gotong-royong ini, kesenian Bangilun berperan sebagai lembaga yang kuat dalam sistem sosialnya. (Suroto : 2019).

Dengan kuatnya sistem kolektif ini Bangilun semakin kuat pula keberadaannya di masyarakat Samigaluh, hingga antara kesenian dan kegiatan kemasyarakatan tidak bisa terpisahkan. Menyatunya antara Bangilun dan masyarakat baik pelaku langsung maupun masyarakat sebagai penyangga budaya, terbentuklah identitas budayanya. Setiap event yang membutuhkan sebentuk kesenian dan kebudayaan, Bangilun diperhitungkan sebagai andalan mereka yang dibanggakan, sebab Bangilun ini tidak dimiliki oleh daerah luar Samigaluh. Seolah ketika berbicara Samigaluh tidak bisa lepas dengan kesenian Bangilun, atau sebaliknya berbicara kesenian Bangilun juga tidak lepas dari masyarakat Samigaluh di mana kesenian ini lahir tumbuh dan berkembang hingga kini (Subardi : 2019).

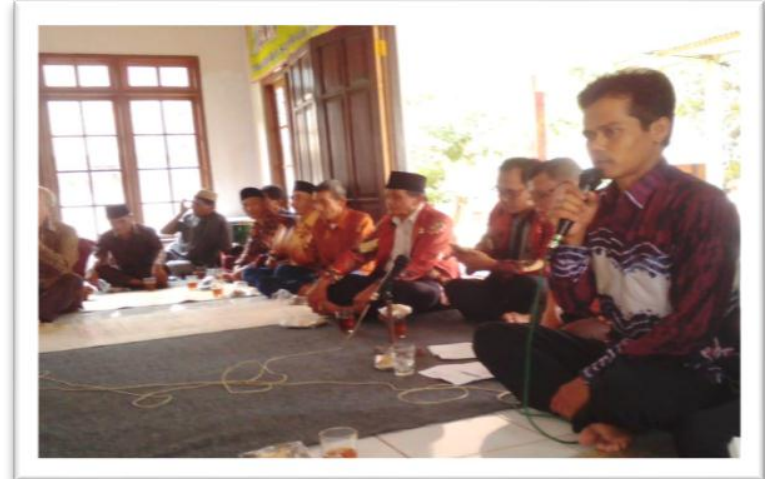

Gb. 02: Lurah Desa Pagerharjo Widayat memberi sambutan saat sarasehan seni Desa Budaya yang melibatkan akademisi, pelaku seni dan budayawan. (foto : Surojo).

Kesenian sudah kerap kali dipakai mewakili seni budaya Samigaluh di event kabupaten dan provinsi. Dengan demikian arus timbal balik antara pemerintah dan kesenian Bangilun sudah lama terjalin hubungan yang baik. Sebagai identitas budaya, kesenian Bangilun terus mengalami perubahan koreografi disesuaikan dengan kebutuhan pertunjukan. Maka dari itu fleksibilitas kesenian Bangilun ini sudah terjadi terutama dalam kurun waktu 10 tahun terakhir ini. Sejalan dengan kemajuan masyarakat Bangilun dituntut menjadi seni pertunjukan yang kreatif dan inovatif agar tidak menjemukan. Dalam setiap pergelaran yang akan disiapkan dibenturkan oleh permintaan pasar yang harus menuruti kehendak pasar. Sikap yang demikian di suatu masyarakat membawa dampak perubahan bentuk penyajiannya. Kesenian Bangilun mau tidak mau, suka tidak suka harus ikut berubah dan berkembang, agar tidak ditinggalkan penonton. Penonton di 
masa sekarang kecenderungannya apabila melihat seni pertunjukan cukup dengan waktu yang singkat dan tidak berlama-lama alias padat dan durasi pendek. Di samping itu masyarakat sekarang pada umumnya menghendaki dan menuntut juga kesenian Bangilun dapat menjadi tontonan dan tuntunan. (Budi Karman : 2019).

Hal yang demikian ini menjadi tantangan di semua pihak, terutama pelaku budaya, bahwa laku kreatif dan mau mengadakan perubahan adalah tuntutan zaman yang harus dipenuhi. Penjagaan komunitas sosial masyarakat di zaman seperti ini tidaklah mudah. Semenjak berkembangnya media sosial dan alat teknologi canggih dapat menenggelamkan kebudayaan lama manusia. Sistem informasi super cepat membawa pengaruh negatif dan positif kesenian Bangilun. Namun sisi positif lah yang sebaiknya dikembangkan agar kesenian Bangilun dikenal di seluruh dunia, sejalan dengan menguatnya identitas budaya sekaligun menjaga keharmonisan dan kedamaian di tengah masyarakat.

\section{c. Sebagai Sarana Hiburan}

Sejalan dengan berkembangnya suatu masyarakat, terutama penyangga kebudayaan, penyajian pergelaran Bangilun masih menjadi andalan untuk menjadi primadona bagi masyarakat Samigaluh. Hal yang demikian terbukti masih seringnya kesenian Bangilun diminta untuk tampil di perhelatan masyarakat sebagai seni profan. Seni tontonan profan artinya dipentaskan tidak lagi sakral sebagai media upacara, namun lebih pada hiburan belaka. Namun demikian pada umumnya setiap penyelenggaraan pertunjukan biasa dibarengi dengan tujuan hajad di tengah masyarakat seperti syukuran atau nadzar saja. Pertunjukan diadakan masih juga banyak pertimbangan bagi penanggap, namun prinsipnya sebagai hiburan saja.

Sebagai sajian seni hiburan baik penanggap maupun seniman dalam group Bangilun yang ditanggap, tetap mempertimbangkan penetapan dan perubahan sajian bentuknya. Dengan kata lain walau kesenian Bangilun dipentaskan sebagai hiburan, justru sebuah kesempatan mengolah dan menggarap kembali ke arah sajian masa kini sesuai dengan kehendak masyarakat penontonnya. Perubahan koreografi yang berubah secara signifikan ketika disusun oleh Widhiharsini. Garapan ini ditandai dengan beralihnya penari laki-laki ke penari putri. Lepas dari pada kualitas dan kuantitas sajian, kemunculan penari putri membawa efek dan dampak tersendiri di kancah pertunjukan di masa tahun 2006-an. 


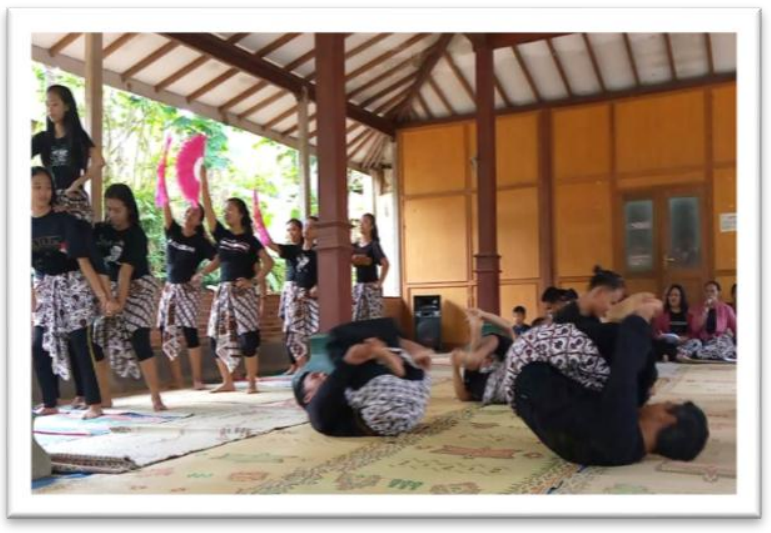

Gb. 03 : Pengolahan desain tari level atas dan level rendah pada koreografi

Kesenian Bangilun. (foto : Surojo).

Durasi waktu pertunjukan yang semula (tari putra) semalam suntuk, maka pada sajian koreografi tari putri cukup pendek maksimal 1 jam. Bahkan untuk kebutuhan tertentu sesuai permintaan diperpendek lagi menjadi 15 menit. Sebagai seni hiburan, waktu yang pendek sangat cocok dilakukan. Pada umumnya permintaan koreografi pendek disebabkan oleh kebutuhan waktu yang tersedia. Yang menjadi problema utama memperpendek sajian adalah juga tidak mudah dilakukan, karena terdapat konsekuensi logis tidak bisa semua isi dan makna tari tersampaikan ke penonton. Banyak sisi yang hilang dan tercampakkan beberapa gerak, namun itulah resikonya.

Yang menarik untuk diikuti dalam perkembangan seni Bangilun sebagai seni hiburan dan tontonan di saat sekarang ini adalah ketika memilih dan menentukan syair yang tersedia itu. Dengan memilih syair secara lansung juga sudah memilih gerakan yang ada. Untuk merangkai dalam sajian bentuk yang utuh dibutuhkan kreativitas penggarapnya, sebab masih harus membuat gerak transisi di antara syair satu dengan syair lainnya. Penambahan gerak transisi ini biasanya dikaitkan dengan kebutuhan pola lantai yang dikehendakinya.

Dalam penyusunan ini yang menjadi tekanan pokok penggarapan adalah seni tari tontonan dan hiburan, maksudnya adalah dari proses kerja latihan itu sudah tampak spirit seni tontonan yang menginginkan sajian terbaik di setiap sajiannya, Maka para penari sangat berpartisipasi saat latihan. Terkadang tanpa guru/penata pun sajian bisa terwujud.

\section{PENUTUP}

$$
\text { Kesenian Bangilun merupakan }
$$
kesenian bernafaskan Islam. Pada awalnya sebagai alat propaganda penyebaran agama Islam di pelosok-pelosok desa. Kesenian yang semula berbentuk sholawat atau seni vokal yang diiringi alat musik terbang dan jedor dilakukan dengan duduk berhadaphadapan, kini telah berkembang pesat menjadi bentuk seni tontonan yang dipentaskan di atas panggung dengan mempertimbangkan kaidah-kaidah hukum seni pertunjukan. Esensi seni Bangilun tidak bergeser dan berubah namun justru lebih kaya akan makna dan fungsinya sebagai seni 
dahwah Islam dan syairnya penuh dengan isian ajaran dan tuntunan hidup manusia. Sebagai seni tontonan dan tuntunan, maka kesenian Bangilun sudah dipadatkan dengan koreografi yang penuh variasi sesuai dengan tuntutan masyarakat masa kini.

Setiap akan disajikan kesenian Bangilun, sekarang ini sudah menggunakan pola atau sistem kerja produksi yang baru, di mana segala rancangan sampai pada pelaksanaan serta target yang akan dicapai sudah dikerjakan dengan pola manajemen modern. Manajemen sebagai sistem kontrol kerja sangat membantu pekerjaan seni pertunjukan menjadi terarah dan ringan dalam masing-masing tugasnya. Bagaimana beban tugas dan tanggung jawab sebagai penari, pengrawit atau crew panggung. Di sini sudah jelas satuan operasional prosedurnya masingmasing. Pekerjaan non artistik yang dibebankan salah satu anggota misalnya kepala rumah tangga akan fokus menyiapkan, konsumsi, kendaraan, kostum dan alat-alat lain yang akan digunakannya.

Sebagai akhir tulisan ini disimpulkan bahwa Kesenian Bangilun di dalam perubahan sajiannya sebatas pada koreografi menyusun urutan syair dan membuat transisi gerak di setiap pergantiannya. Dengan urutan dan penggunaan syairnya akan dapat menentukan koreografi/penyajian keenian Bangilun itu panjang atau pendek sesuai denga kebutuhan pentas. Penggunaan syair lagu hingga saat ini menjadi pokok penting dalam menyusun tarian, dan belum pernah terjadi tarian diciptakan secara tersendiri lepas dari nyanyiannya. Dengan kata lain dengan berbagai perubahan koreografi selama ini, tidak mengubah pokok dan inti tarian. Yang berubah hanyalah durasi waktu penyajian. Perubahan penyajian ini semata berdasarkan perubahan di dalam masyarakat itu sendiri, misalnya waktu penyajian menjadi luwes bisa 5 menit, 10 menit, atau 30 menit, tanpa harus dipertontonkan selama semalam suntuk.

\section{DAFTAR SUMBER ACUAN}

\section{A. Sumber Tertulis}

Burger, D.H. 1983, Perubahan-Perubahan Struktur Dalam Masyarakat Jawa, Terjemahan

Dewan Redaksi, Bharata Karya Aksara, Jakarta.

Geertz, Clifford. 1973. The Interpretation of Culture. New York : Basic Books. Goode,

William J.

Hersapandi. 1991 "Wayang Wong Sriwedari : Suatu Perjalanan Dari Seni Istana

Menjadi Seni Komersial, 1901 1991." Tesis untuk meraih derajat Sarjana S-2 di Universitas Gadjah Mada Yogyakarta.

Hadi, Y. Sumandiyo. 2001. Pasang Surut Tari Klasik Gaya Yogyakarta, Pembentukan 
Perkembangan Mobilitas. Lembaga Penelitian ISI Yogyakarta, Yogyakarta.

Ivanovich Agusta . 2003. (Makalah Metode Penelitian Kualitatif di Pusat Penelitian Sosial

Ekonomi) Bogor.

Nin Bakti Sumanto (terj.). 1991. Klasik, Kitsch, Kontempoter: Sebuah Studi Tentang

Seni Pertunjukan Jawa. (Lindsay, Jennifer.. Klasik, Kitsch or Contemporary: A

Study of the Javanese Performing Arts), Yogyakarta. Gadjah Mada University Press.

Saiffudin Anwar, 2005. Metode Penelitian. Pustaka Pelajar. Yogyakarta.

Sedyawati, Edi. 1981. Pertumbuhan Seni Pertunjukan, Jakarta: Sinar Harapan.

Sedyawati Edi, 1984. Tari: Tinjauan Dari Berbagai Segi, Jakarta : Pustaka Jaya.

Soedarsono, R.M. 1979/1980. Beberapa Faktor Kemunduran Wayang Wong gaya

Yogyakarta. Yogyakarta : ASTI.

Soedarsono, R.M. 1985. Pola Kehidupan Seni Pertunjukan Masyarakat Pedesaan. Dalam

Djoko Suryo, R.M. Soedarsono, Djoko Soekiman. Gaya Hidup Masyarakat Jawa di Pedesaan : Pola Kehidupan Sosial - Ekonomi dan Budaya. Yogyakarta : Proyek Javanologi.

Soedarsono, R.M. 2002. Seni Pertunjukan Indonesia di Era Globalisasi, Yogyakarta:

Gadjah Mada University Press.

\section{B. Nara Sumber :}

Budi Karman ketua paguyuban "Sedya Rukun" dan pelatih iringan Bangilun Plono Barat

Didik Nuryanto, 48 tahun, Kasi di Disparpora Kab. Temanggung

Puji Lestari, 42 tahun, Guru tari, pengurus Rintisan Desa Budaya dan aktivis kesenian di Gerbosari Samigaluh.

Sarjo, 72 tahun tokoh dan mantan Ketua Desa Budaya Pagerharjo Samigaluh

Subagyo 56 tahun, guru seni karawitan dan aktivis budaya di Samigaluh.

Subardi, 55 tahun, Dalang dan pengelola Desa Budaya Pagerharjo Samigaluh

Suroto, 70 tahun, tokoh dan budayawan desa Pagerharjo Samigaluh

Sri Lestari, 54 tahun pelatih Bangilun "Sedya Rukun" Plono Barat Pagerharjo Samigaluh. Widhiharsini, 46 tahun, Guru dan aktivis seni di Samigaluh

Widayat, 38 tahun, Kepala Desa Pagerharjo Kec. Samigaluh, Kab. Kulon Progo DIY. 
